Association for Information Systems

AIS Electronic Library (AISeL)

Wirtschaftsinformatik 2021 Proceedings

Track 19: IT Strategy, Management \&

Transformation

\title{
Digital Business Strategy and Firm Performance: An Empirical Investigation
}

Hannes Kurtz

Georg-August-Universität Göttingen

Andre Hanelt

Universität Kassel

Sebastian Firk

University of Groningen

Follow this and additional works at: https://aisel.aisnet.org/wi2021

Kurtz, Hannes; Hanelt, Andre; and Firk, Sebastian, "Digital Business Strategy and Firm Performance: An Empirical Investigation" (2021). Wirtschaftsinformatik 2021 Proceedings. 5.

https://aisel.aisnet.org/wi2021/FITStrategy19/Track19/5

This material is brought to you by the Wirtschaftsinformatik at AIS Electronic Library (AISeL). It has been accepted for inclusion in Wirtschaftsinformatik 2021 Proceedings by an authorized administrator of AIS Electronic Library (AISeL). For more information, please contact elibrary@aisnet.org. 


\title{
Digital Business Strategy and Firm Performance: An Empirical Investigation
}

\author{
Hannes Kurtz ${ }^{1}$, Andre Hanelt ${ }^{1}$, Sebastian Firk ${ }^{3}$ \\ ${ }^{1}$ Georg-August-University Göttingen, Information Management, Göttingen, Germany \\ hannes.kurtz01@ stud .uni-goettingen.de \\ ${ }^{2}$ University of Kassel, Digital Transformation Management, Kassel, Germany \\ hanel1@ uni-kasselde \\ ${ }^{3}$ University of Groningen, Management Accounting, Groningen, Netherlands \\ s.firk@ rug.nl
}

\begin{abstract}
While digital business strategy (DBS) has recently garnered substantial attention, there is still little understanding about different strategy alternatives and their outcomes. However, this is of great importance as different digital business strategy types may utilize different profit mechanisms and thus influence a companies' performance in different ways. We conceptualize four distinct digital business strategy types and examine their influence on firm performance by applying panel fixed effect regression to a longitudinal dataset comprising leading tech companies. We find that not all digital business strategy types achieve to result in a positive impact and derive implications for information systems research and business practice.
\end{abstract}

Keywords: IS Strategy, Performance Implications, Panel Data Regression, Fixed-Effect Regression, Digital Business Strategy Types

\section{Introduction}

Digital technologies are fundamentally reshaping conventional wisdom about scope, scale, design and execution of business strategy. Accordingly, we have witnessed a fusion of information technology (IT) and business strategy, which led to the introduction and elaboration of the concept of digital business strategy (DBS). Digital business strategy is defined as "organizational strategy formulated and executed by leveraging digital resources to create differential value” [1]. Given the importance of this topic for contemporary managerial practice, increasingly more researchers have been devoting themselves to the research area of digital business strategy. While some have focused their further theoretical elaboration on the concept [2], others investigated performance implications of digital business strategy [3]. Though valuable advances have undoubtedly been made by these research efforts, we believe that certain gaps remain.

For example, to the best of our knowledge, there is no evidence regarding different strategy types and their implications on firm performance as there is in classical strategy research. Here, researchers assume that strategies consist of a limited number of sets of observable and recurring configurations that can be grouped and generalized into

16th International Conference on Wirtschaftsinformatik,

March 2021, Essen, Germany 
archetypes [4].There are a multitude of typologies in the realm of strategy research that all relate to different aspects of business strategy [e.g. 5-7]. At the same time, increasing digitalization influences many of these aspects, which calls into question the timeliness of these concepts. For example, digital technologies enable companies to tap into new sources of value creation and capturing [8], which in turn, results in new profit mechanisms [2]. Hence, filling the gap of missing digital business strategy types regarding value creation mechanisms and investigating their effects on firm performance is of importance. Accordingly, we investigate the following research question: How do different digital business strategy types influence firm performance? To provide answers to this research question, we start by systematically and conceptually deriving four types of digital business strategy by using relevant literature and the business model pattern database derived by Remane et al [9]. Afterwards, we theorize the relationship between the four types of digital business strategy and firm performance. Subsequently, we empirically investigate a longitudinal sample of companies from the NASDAQ 100 over the period from 2007 to 2017 using aforementioned business model patterns to visualize employed digital business strategy types in respective companies. Employing firm fixed-effect regression, we find that not all digital business strategy types positively affect firm performance. While the DBS aimed at the development of IT applications ${ }^{1}$ has a negative effect, the intermediation in two-sided markets does not exhibits a significant effect. Emphasizing the DBS aimed at the orchestration of digital business ecosystems and the DBS focusing on the processing of intellectual property, in contrast, positively impact firm performance. Our work provides important contributions to information systems (IS) research on digital business strategy [1]. First, we systematically derive and conceptualize four different types of digital business strategy. Second, we provide insights concerning the influence of different digital business strategy types on a company's performance. Third, on the base of our empirical findings, we discuss the value of the digital business strategy types for IS research and business practice.

\section{Theoretical Foundations}

Strategy is often defined as a set of committed choices made by management and a contingent plan of actions and activities designed to achieve a particular goal [10]. These choices relate to topics such as resource investments or the set of a firm's dynamic capabilities which are needed to deploy these resources [2]. Even if companies formulate and execute business strategy in response to their individual environment, structure and processes [11] it is possible to detect patterns in this stream of decisions that apply to a large number of companies with different contextual dependencies [12]. These patterns can be generalized and, thus, can be understood as archetypical [4]. Accordingly, different typologies focusing on different aspects of business strategy, exist. One of the most popular typologies is the one developed by Miles and Snow [7]

${ }^{1}$ We define IT applications according to Ivari [79] as "a system of application software and digital content or a piece of application software - that provides its users with services of affordances

16th International Conference on Wirtschaftsinformatik, March 2021, Essen, Germany 
focusing on strategic behavior of companies (i.e. its tendency to innovate, lead, and take risks) [13]. This typology has often been applied in IS research, for instance, in order to classify the strategic use of information technology and its implications on firm performance [e.g. 14-16]. However, almost all named articles have in common that they can be dated to the pre-digital era and/or represent and examine the alignment view of business and IT strategy. Simultaneously, digital technologies are fundamentally reshaping the competitive landscape and therefore the business strategy [17-19]. Ongoing digitalization, thus, contributes to a fusion of IT and business strategy. This leads to the emergence of the concept of digital business strategy defined as "organizational strategy formulated and executed by leveraging digital resources to create differential value" [1]. Recently, several studies have been devoted to further develop and enrich the theoretical understanding of digital business strategy and its influence on firm performance. Leischnig et al. [3], for instance, empirically examine the transformation of a firm's digital business strategy into market performance, considering the intervening roles of market intelligence and subsequent value creation and value capture. They conclude that digital business strategy is positively linked to enhanced market intelligence capability, leading to the generation of market-oriented knowledge resources as important inputs for operative and strategic decision making. Mithas and Rust [20], empirically examine how information technology strategy and investments in IT influence firm performance. The results show that the use of digital technologies can influence the performance of a firm in three ways: Firstly, it can reduce a firm's cost by improving its productivity and efficiency. Secondly, it can reduce costs and increase value simultaneously. Lastly, it can increase a firm's revenues by fully exploiting opportunities through existing or by finding and creating new customers, channels and products or services. Drnevich and Croson [2], in contrast, point out ways for an integrated theoretical perspective on information technology and business level strategy and link them to casual profit mechanisms of different theoretical perspectives on strategy.

Taking the aforementioned into account, there are still many gaps when it comes to the topic of digital business strategy. A major shortcoming of all previous and particularly of conceptual studies in information system research is that they treated digital business strategy in an undifferentiated manner. Different digital business strategy types, however, can use different profit mechanisms. Consequently, they influence a company's performance in different ways [2]. Therefore, a more differentiated consideration is needed, shedding light on the influence different digital business strategy types have on a company's performance.

\section{$3 \quad$ Making Digital Business Strategy Tangible via Digital Business Model Patterns}

A business model describes the way in which companies create and capture value [21, 22]. Furthermore, the business model in its firm-specific conception allows to describe and design specific components as well as the interactions between those [22]. Therefore, the business model concept is a useful lens for understanding a company's 
underlying logic $[23,24]$ and, as a consequence, can be understood as "reflections of the realized strategy" [10]. Business models, on the one hand, translate abstract strategic notions into more concrete configurations of resources and activities, thereby informing about the specific paths that strategies lead to [25]. Business models thus represent a conceptual tool for analyzing business strategies. On the other hand, business models of particular firms are very specific and contextualized. Therefore, in order to systematically learn about business strategies via business models, some abstraction is needed. Such abstraction is provided by business model patterns. Put simply, business model patterns are commonly used and proven successful configurations of specific components of a business model [26], and thus can be used as a systematic tool for analyzing company's business model [28]. Synthesizing the variety of existing business model patterns, Remane et al. [9] built up a database of 182 business model patterns in their study. In the resulting taxonomy, they differentiate, among others, between purely digital, digitally enabled and not necessarily digital patterns. They also used the dimensions prototypical, which addresses patterns describing the general set-up of a company's business model and solution, which addresses patterns aiming to change only sub aspects of the business model. In addition, patterns have been classified by four meta-components and related sub-dimensions. The value proposition, gives an overall view of a company's products and services. Value delivery, describes the customer segments, channels for delivering the value proposition and the company's customer relationship. Value creation, explains the key resources, key activities and key partnerships of a company. Value capture, specifies the company's revenue streams and cost structure [9]. For the purpose of deriving DBS types, only the 28 business model patterns which are purely digital and prototypical will be considered.

We iterated between the meta-components as well as their corresponding subdimensions of the database and contemporary IS and strategy research to extract criteria for the identification of digital business strategy types. In doing so, we were able to identify four digital business strategy types with different profit mechanisms. Using the pattern descriptions contained in the database as well as the corresponding taxonomy we were able to manually assign the 28 patterns to the individual DBS types. Below is a more detailed description of these four DBS types and a brief summary in Table 1.

\section{Digital Business Strategy Type 1 - Development of IT Applications}

This digital business strategy type uses the potential of knowledge-based innovation in a digital context by designing unique, digital value propositions to address specific customer needs [29, 30]. Central mechanism of value creation is the development of new digital products and the economic exchange of those [31]. Companies applying this digital business strategy type usually get a payment for licenses or earn a usage fee and, as a consequence, rely on patents and other trade secrets to exploit their innovations effectively [32, 33]. An example are software firms, where new functionality, application concepts, and design patterns that promise the customer more added value, are constantly embedded [24, 30]. 


\section{Digital Business Strategy Type 2 - Processing of Intellectual Property}

The second digital business strategy type takes advantage of the ongoing digitalization of intellectual property [34]. Central mechanism of value creation is the efficient leveraging of own and externally created digital information and content by aggregating, transferring or further processing this data [1]. Companies applying this digital business strategy type, for instance, gain economic value by reutilizing this externally created intellectual property in more useful ways or by analyzing this data $[35,36]$. An example are search engines, accumulating available information from the internet and subsequently making it accessible for consumers in a convenient way [24].

\section{Digital Business Strategy Type 3 - Intermediation in Two-Sided Markets}

This digital business strategy type uses the multisided-nature of economic exchange to create value. Central value creation mechanism is the efficient design of exchanges by otherwise fragmented parties [31, 37]. In doing so, companies design particular interaction mechanisms between supplier and customer in a more efficient and convenient way for both sides by, for instance, decreasing search costs, offering a wide selection range or providing symmetric information through a digital platform or a portal [31,38]. The online restaurant reservation business or job portals are good examples, since they offer easy access to a vast number of offers and considerably facilitate the selection and interaction with these offers [38].

\section{Digital Business Strategy Type 4 - Orchestration of Digital Business Ecosystems}

The final digital business strategy type uses complementarities and an ecosystem approach [38]. Central value creation mechanism is facilitating and orchestrating of an innovation ecosystem, in which multiple complementors can add their innovations and in doing so, increase the value of the system as a whole [37, 39]. These patterns lead to the creation of lock-in effects resulting from switching-costs and positive network effects [31]. Examples for such ecosystems is Apple's digital mobile platforms iOS with the corresponding application ecosystems [33, 38].

Table 1. Digital Business Strategy Types, their descriptions and patterns

\begin{tabular}{lll}
\hline Strategy Name & \multicolumn{1}{c}{ Description } & \multicolumn{1}{c}{ Corresponding Patterns } \\
\hline $\begin{array}{l}\text { Development of } \\
\text { Digital } \\
\text { Applications }\end{array}$ & $\begin{array}{l}\text { Constant and independent (further) } \\
\text { development of new IT applications } \\
\text { and their economic exchange. }\end{array}$ & $\begin{array}{l}\text { Network utility provider, (Virtual) selling } \\
\text { experience, Selling online services, Selling } \\
\text { virtual accessories, Software firms, Trust } \\
\text { services }\end{array}$ \\
$\begin{array}{l}\text { Processing of } \\
\begin{array}{l}\text { Intellectual } \\
\text { Property }\end{array}\end{array}$ & $\begin{array}{l}\text { Leveraging of intellectual property by by } \\
\text { aggregating, transferring or further } \\
\text { processing it. }\end{array}$ & $\begin{array}{l}\text { Content (access) provider, Context, Horizontal } \\
\text { portals, Information collection, IP trader, Open } \\
\text { content, Vertical portals }\end{array}$ \\
$\begin{array}{l}\text { Intermediation } \\
\text { in Two-Sided } \\
\text { Markets }\end{array}$ & $\begin{array}{l}\text { More efficient design of exchanges by } \\
\text { otherwise fragmented parties by } \\
\text { decreasing transaction costs. }\end{array}$ & $\begin{array}{l}\text { Aggregation, Agora, Classifieds, Demand } \\
\text { collection systems, Infomediary, Online } \\
\text { brokers, Search agent, Transaction service and } \\
\text { exchange intermediation, Trust intermediary }\end{array}$ \\
$\begin{array}{l}\text { Orchestration of } \\
\text { Digital Business } \\
\text { Ecosystems }\end{array}$ & $\begin{array}{l}\text { Facilitation and orchestration of a } \\
\text { digital business ecosystem in which } \\
\text { multiple parties can participate. }\end{array}$ & $\begin{array}{l}\text { Collaborations platforms, E-Mall, Marketplace } \\
\text { exchange, Multi-sided platforms, Value chain } \\
\text { integrator, Virtual community }\end{array}$ \\
\hline
\end{tabular}




\section{$4 \quad$ Hypotheses Development}

In the competence based perspective, the economic profit mechanism for firms focuses on the balance between value creation and value capture [2]. Digital technologies enable companies to tap into new sources of value creation and capturing [e.g. 1, 8, 40]. In their popular work, Amit and Zott [31], specify novelty, efficiency, complementarities and lock-in as sources of value creation. Companies can create value based on one of these sources but also have the chance to use a combination of different sources for creating value. Novelty refers to new transaction structures, transaction content and participants. Efficiency in contrast, is aiming for cost reduction of already existing transactions such as search costs, simplicity and scale economics [41]. Complementarities refer to the interdependency between products and services, strategic assets, or several technologies. This means that a bundle of products provides more value than having each of the products separately. Lock-in focuses on prevention of migration of customers and strategic partners. Examples for named effect are switching costs of or positive network effects [31]. Our hypotheses base on the assumption that the individual digital business strategy types "trade off efficiency (i.e., maximizing joint profitability through value creation) through the effective use of resources against the distribution of returns from its efforts,[...] (i.e., maximizing producer surplus through value capture)" [2], differently. Ultimately this impacts a company's performance in different ways.

Regarding Amit and Zott's [31] sources of value creation, the first digital business strategy type merely focuses on novelty. In an ever more digitally mediated world there is a high market potential for new digital products [42, 43], which favors the digital business strategy type. On the other hand, there are several problems which occur with this DBS. Firstly, companies using this DBS often operate in a hyper-competitive environment, creating substantial pressure on prices [44]. This is reinforced by the fact that customers often show little willingness to pay for digital goods which can also be seen in the trend towards open software [45]. Secondly, companies pursuing this DBS are under pressure to further develop their offerings constantly to keep pace with technological advances and customer preferences, making it an investment-heavy business [8] and a less efficient digital business strategy. As a consequence, we formulate the following hypothesis: Hypothesis 1: Applying a digital business strategy aimed at the development of IT applications has a negative influence on a firm's performance.

The second digital business strategy type is based mainly on efficiency but to some extent also on novelty as sources of value creation. Customers increasingly prefer to consume information and content online [46]. At the same time information goods exhibit fixed costs but almost zero marginal costs for their production and distribution [47]. Additionally, once created, online content often can be used and processed multiple times, allowing to monetize it more than once [19]. Furthermore, socialcomputing has a positive impact on the companies' costs as the customer can be involved in the value creation process $[48,49]$. All together this leads to increased 
efficiency. At the same time, it is easy for companies pursuing this DBS to fine-tune their activities and develop new offerings, as it is easy for them to identify relevant content on the basis of the customers' engagement and their preferences that can be obtained from data [1]. Accordingly, we present the following hypothesis: Hypothesis 2: Applying a digital business strategy aimed at the processing of intellectual property has a positive influence on a firm's performance.

The digital business strategy type aimed at the intermediation in two-sided markets uses lock-in as source of value creation. The internet plays a decisive role in a customer's purchasing decision [50]. As a result, there is a high demand for companies providing a digital service that enables interactions between multiple sets of agents [51, 52]. In doing so, the intermediator, pursuing this DBS, tries to generate lock-ins by creating value for agents on both sides through the reduction of transaction costs [40]. Since value is created for agents on both sides, the intermediary has the opportunity to generate revenue from both and can thus maximize profit [53]. At the same time, the intermediary has the possibility to be remunerated in numerous ways, e.g. through fees for membership or transaction [52] as well as for listing prices [54] or advertising [51]. Accordingly, we present the following hypothesis: Hypothesis 3: Applying a digital business strategy aimed at the intermediation in two-sided markets has a positive influence on a firm's performance.

The fourth digital business strategy type uses all four sources of value creation. These are novelty, efficiency, complementarities, and lock-in. Ecosystems based on digital platforms are increasingly important in the provision of products and services [55]. These platforms create business value by encouraging participation of customers and complementary third-party innovation of business partners. In doing so, the platform owner is able to exploit indirect network effects [56]. The platform owner benefits in several ways [57], such as by outsourcing the innovation processes and entrepreneurial risk to complementors and subsequently monetizing transactions between these complementors and customers $[19,58,59]$ making this DBS more efficient. In addition, through the participation of multiple actors within the innovation process as well as the possibility of direct customer feedback, innovations and novel products often turn out to be more relevant and address customer demands more precisely [60]. We therefore define the following hypothesis: Hypothesis 4: Applying a digital business strategy aimed at the orchestration of digital business ecosystems has a positive influence on a firm's performance.

\section{$5 \quad$ Methodology}

We investigated a longitudinal sample of tech-savvy companies between 2007 and 2017, focusing on firms in the NASDAQ-100 index and using 2007 as a starting point for our data collection. The NASDAQ-100 lists the largest 100 stocks according to market capitalization traded on the NASDAQ (National Association of Securities Dealers Automated Quotation). We decided to delimit the sample to firms in clearly 
technological SIC (Standard Industrial Classification) industry groups. Specifically, we focus on SIC groups (357) Computer and Office Equipment and (737) Computer Programming, Data Processing, And Other Computer Related Services. The reduction to companies from these two industry groups ensures a relatively homogeneous sample, when it comes to industry characteristics and relevance of digital business strategy per se. As a result, 50 companies were excluded. Moreover, we needed to exclude firmyears that did not provide Form 10-K reports required to decode the different business model strategies. Finally, we collected data on firm performance and financial controls for the remaining firm-years from the Datastream database. This process resulted in a final sample consisting of 235 firm-years of 43 firms between 2007 and 2017.

Subsequently, in order to identify the applied digital business strategy of each company within our sample in the respective years, we compared the respective business descriptions within the Form 10-K's with the descriptions of the 28 purely digital and prototypical patterns identified by Remane et al. [9]. By using Form 10-K, we followed previous research [e.g. 61, 62], relying on this source to obtain information about a company's business model. For the sake of verifiability, we marked company statements matching the description of a specific pattern within the Form $10-\mathrm{K}$ with the corresponding designation and within a matrix consisting of the individual companies and the digital business model patterns. Moreover, several rules and guidelines for granting verifiability and avoiding possible mistakes were adhered to by following the established deductive approach of qualitative content analysis [63]. Certain statements open to consideration for several patterns were marked and later discussed among the scholars. Additionally, no more than 30 Form 10-K's were encoded per session and the results of previous sessions were checked in advance of each new session. Furthermore, after half of the data had been analyzed and coded, the results were compared, discrepancies in the coding were discussed as well as corrected and anchor examples were set. The remaining Form 10-K's were encoded by following these anchor examples.

\section{Measures}

\section{Independent Variable: Digital Business Strategy}

The four derived digital business strategy types are used as dummy variables, indicating whether a specific digital business strategy was applied in the respective year. These dummy variables, representing the individual digital business strategy, consist of the corresponding purely digital and prototypical business model patterns applied by the companies within the respective years. Companies might show different patterns representing different digital business strategy and thus may apply several digital business strategy types simultaneously. The mix of strategies applied can therefore be subject to change over time.

\section{Dependent Variable: Performance}

We use Tobin's Q to investigate the influence of digital business strategy on firm performance. We chose Tobin's Q as a forward-looking and risk-adjusted measure less 
susceptible to changes in accounting practices [64]. Moreover, the measure is widely used in information systems research and has been applied in several well-known studies examining the influence of investments in IT and digital technologies on a company's performance [e.g. 20, 65-67]. Our study is therefore in line with a multitude of other studies that use the $q$ ratio to describe the intangible value of a company. Thereby, the underlying assumption is, that "the long-run equilibrium market value of a firm must be equal to the replacement value of its assets, giving a $q$ value close to unity. Deviations from this relationship (where $q$ is significantly greater than " 1 ") are interpreted as signifying an unmeasured source of value, and generally attributed to the intangible value enjoyed by the firm" [65]. This intangible value also relates to the value and influence of a strategy on the performance of a company. We define Tobin's $\mathrm{Q}$ as market value divided by the replacement value of its assets.

\subsection{Control Variables}

We include a broad set of control variables to allow for other factors that may affect the performance of a company. We use commonly applied controls in empirical studies on innovation outcomes. All data has been obtained from Thomson Reuters Datastream. These measures together with their underlying calculation are listed in the following Table 2.

Table 2. Control variables and corresponding underlying calculations

\begin{tabular}{ll}
\hline Variable & Calculation \\
\hline Firm Size & Natural logarithm of firm’s net sales \\
Leverage & Ratio of total debt to total assets \\
Net Profit Margin & $\begin{array}{l}\text { Measured as net operating profit margin, which equals income divided by net sales. } \\
\text { Measured in percent } \\
\text { One-Year growth of a firm's net sales in percent } \\
\text { Growth }\end{array}$ \\
Liquidity & $\begin{array}{l}\text { Calculated as cash divided by total assets and then multiplied by } 100 \\
\text { Ratio of R\&D spending by net sales and then multiplied by } 100 \text { (R\&D over firm } \\
\text { sales, where missing R\&D is considered as zero) } \\
\text { Calculated as capital expenditures divided by net sales and then multiplied by } 100 \\
\text { Capex }\end{array}$ \\
Capital Intensity & $\begin{array}{l}\text { Natural logarithm of one plus the ratio between property, plant, and equipment and } \\
\text { then number of employees }\end{array}$ \\
\hline
\end{tabular}

\subsection{Model Specifications}

To examine the influence of different digital business strategy on a firm's performance, we need to address several empirical challenges. First, firm performance may be influenced by various unobserved factors. To account for this, we exploit our longitudinal design and decide to focus on a firm-fixed effects regression similar to prior research $[68,69]$. In such a firm-fixed effects regression, each firm is assigned an individual effect to control for firm-specific unobservable factors, resulting in only time-variant effects within a firm being estimated. In our case, we therefore estimate the influence of changing one of our digital business model strategy variables (e.g., the 
adoption or abandonment of the respective strategy) on the company's performance. Second, we need to control for exogenous shocks like the financial crisis in 2008 and hence include annual fixed effects in addition to our control variables. Based on this, we use the following model with Tobin's $\mathrm{Q}$ as a dependent variable to analyze Hypotheses 1-4 (the item fixedj includes the firm-specific effects in the fixed effects regression):

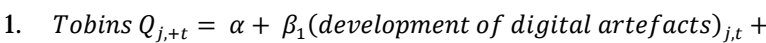

$\beta_{1}$ (processing of intellectual capital $)_{j, t}+\beta_{1}$ (intermediation of twosided markets $)_{j, t}+$

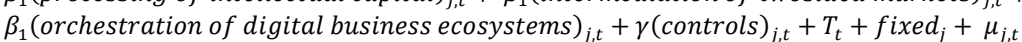

\section{$7 \quad$ Regression Results}

Table 3 displays the means, standard deviations and pairwise correlations of primary variables. Due to partially strong correlation among specific control variables, we investigate variance inflation factors to check for multicollinearity. All resulting values are below critical thresholds (highest $=2.26$ ), concluding that our analysis is not constrained by multicollinearity [70].

Table 3. Summary statistics and correlation coefficients

\begin{tabular}{|c|c|c|c|c|c|c|c|c|c|c|c|c|c|c|}
\hline Variable & Mean & $\begin{array}{l}\text { Std. } \\
\text { Dev }\end{array}$ & 1 & 2 & 3 & 4 & 5 & 6 & 7 & 8 & 9 & 10 & 11 & 1213 \\
\hline 1. DBS I & 0.67 & 0.47 & 1 & & & & & & & & & & & \\
\hline 2. DBS II & 0.34 & 0.47 & -0.43 & 1 & & & & & & & & & & \\
\hline 3. DBS III & 0.18 & 0.38 & -0.15 & 0.25 & 1 & & & & & & & & & \\
\hline 4. DBS IV & 0.29 & 0.46 & -0.16 & 0.47 & 0.43 & 1 & & & & & & & & \\
\hline 5. Tobin's $Q^{*}$ & 2.13 & 1.09 & 0.03 & -0.15 & -0.07 & 0.08 & 1 & & & & & & & \\
\hline 6. Size & 15.77 & 1.33 & -0.23 & 0.23 & -0.08 & 0.26 & 0.05 & 1 & & & & & & \\
\hline 7. Leverage & 20.88 & 19.55 & -0.09 & 0.10 & 0.09 & -0.26 & 0.08 & -0.02 & 1 & & & & & \\
\hline 8. Net Profit Margin & 19.06 & 14.86 & 0.10 & -0.01 & -0.15 & -0.13 & 0.36 & 0.12 & 0.11 & 1 & & & & \\
\hline 9. Growth* & 9.39 & 13.07 & -0.20 & 0.05 & -0.03 & 0.12 & 0.30 & 0.19 & -0.15 & 0.11 & 1 & & & \\
\hline 10. Liquidity & 14.89 & 12.91 & 0.02 & -0.02 & -0.11 & 0.01 & 0.04 & -0.25 & -0.15 & -0.06 & -0.20 & 1 & & \\
\hline 11. $R \& D$ Intensity & 11.88 & 10.06 & 0.39 & -0.26 & -0.19 & 0.06 & 0.12 & -0.15 & -0.25 & -0.18 & -0.15 & 0.29 & 1 & \\
\hline 12. Capex & 5.16 & 4.03 & 0.00 & 0.14 & 0.14 & 0.03 & 0.02 & 0.25 & 0.05 & 0.08 & -0.03 & -0.23 & -0.08 & 1 \\
\hline 13. Capital Intensity & 4.28 & 1.04 & -0.10 & 0.30 & 0.10 & 0.10 & 0.02 & 0.24 & 0.35 & 0.09 & 0.04 & -0.30 & $-0.05 c$ & 0.581 \\
\hline
\end{tabular}

*Variables Tobin's Q and Growth are winsorized at level 5\% and 95\%.

To test our hypotheses, we investigated a firm-fixed effect regression to calculate the impact of specific digital business strategy on a company's performance while controlling for various confounding effects. We find a highly significant and negative influence on firm performance with regard to the development of IT applications $(\mathrm{p}<.01)$ supporting our first hypothesis. Regarding the digital business strategy to focus on processing of intellectual property, we find a positive and highly significant $(\mathrm{p}<.05)$

16th International Conference on Wirtschaftsinformatik, March 2021, Essen, Germany 
influence on firm performance. Hence, our results support our second hypothesis. In contrast, we cannot identify any significant influence regarding the strategy on intermediation in two-sided markets. While we find a negative coefficient for the influence on firm performance, as suggested in our third hypothesis, the coefficient turns out to be insignificant. Finally, regarding the orchestration of digital business ecosystems, our results indicate a highly significant $(\mathrm{p}<.01)$ and positive impact on firm performance supporting our fourth hypothesis. Table 4 displays the results of these regressions.

Table 4. Results of fixed effect regressions on a firm's performance

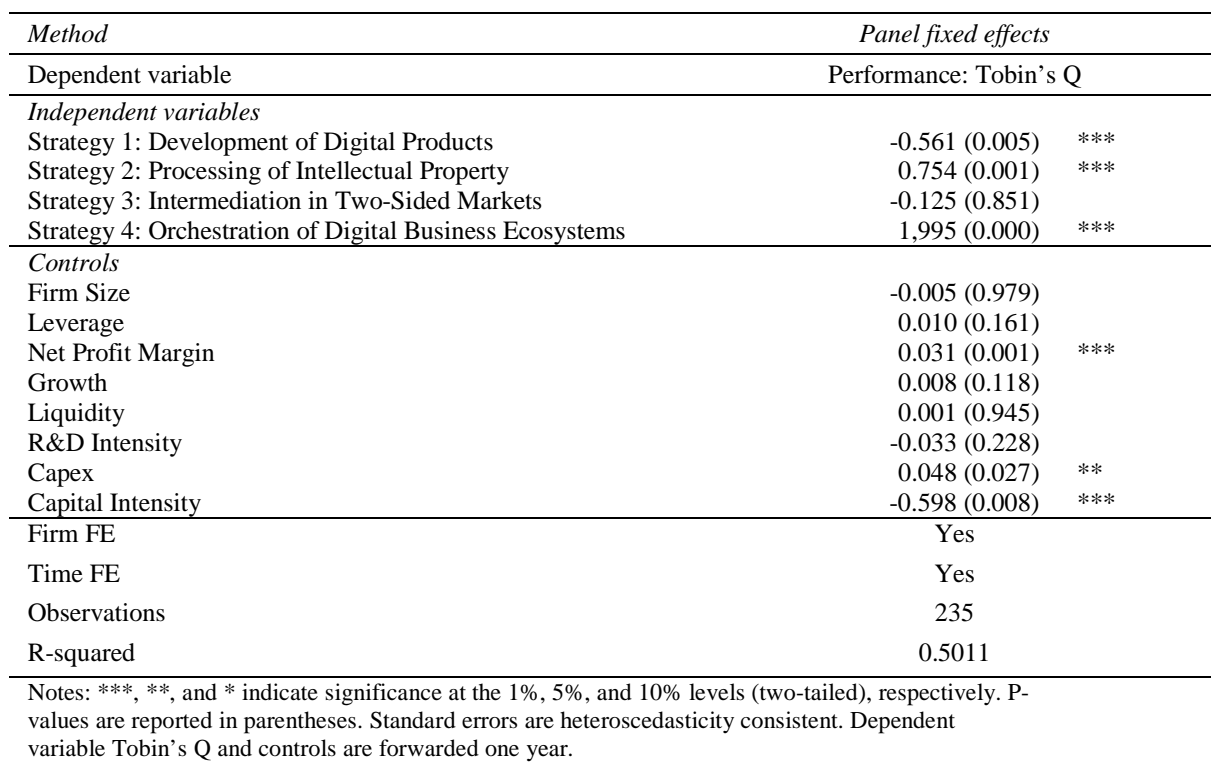

\section{Discussion of Findings}

Our findings indicate that there is a negative relationship between the digital business strategy type development of IT applications and firm performance. This result suggests that companies do not profit from the development of IT applications on average. A possible reason may be the general problem of profitably commercializing IT applications within a highly competitive environment. This strategy highly depends on a strong protection against imitation via appropriability regimes. With regard to digital technologies, these regimes are often weak since it is easy to decode them and legal protection is inefficient $[71,72]$. Besides, in some cases, it is easy for competitors to invent around these patents at modest costs [73, 74]. Finally, digitalization fosters the substitutability of intellectual property, leading to the value of patents to further diminish [72, 75].

Regarding the digital business strategy type processing of intellectual property, our findings indicate a positive relationship with firm performance. This result suggests 
that the performance of a company is positively affected by the processing of intellectual property. Main reasons for this may be the versatile use of generated information and digital content, accompanied by low costs for their production and distribution [47, 76]. Companies applying this approach have the opportunity to monetize the same content multiple times and in different ways. Content, for example, can be delivered for free in order to attract a large number of customers and encourage participation. The actual added value takes place in various downstream businesses, such as data analytics and brokerage or advertising placement [35, 48].

With reference to the relationship between the digital business strategy type intermediation in two-sided markets and a company's performance, our results indicate an insignificant influence and do not allow for conclusions about positive or negative correlations between these two. Other reasons could be that positive and negative effects outweigh each other. Profit-maximization is difficult in these businesses, since it will restrict network participation by pricing out some potential participants. Generating profit from both sides is an even greater obstacle, as it prices out yet more potential participants [53]. On the other hand, the technological and market lock-in is weak, making it easy for agents on both sides to migrate to other intermediators [38]. This competition between platforms often leads to openness to attract more customers which, in turn, frequently causes decreases in differentiation and the ability to capture value, since an important source of competitive advantage is the exclusive access to their networks [52, 57].

Findings from our panel data regression show that there is a positive relationship between the digital business strategy type orchestration of digital business ecosystems and firm performance. This supports the suggestion of a positive influence on the performance of companies pursuing this digital business strategy type. Possible reasons may be the indirect network effects such ecosystems often create, together with the decisiveness of companies at the center of such ecosystems. The platform owner has the opportunity to control key components inside and outside the ecosystem. This decreases complementors' bargaining power and, at the same time, enables the platform owner to exploit products and services with high margins for himself [77]. As a consequence, companies at the center of ecosystems can appropriate more value from innovations within the ecosystem [38, 58, 72].

\subsection{The Value of Digital Business Strategy Types for IS Research and Business Practice}

Our findings reveal important implications for theory and practice. Firstly, while Leischning et al., [3] state that digital business strategy is positively linked to enhanced market intelligence capability, leading to superior market performance, we can show that this is only valid to a limited extent. Only the derived digital business strategy types, processing of intellectual property, intermediation in two-sided markets, and orchestration of digital business ecosystems show an enhanced market orientation. Furthermore, only the latter exhibits a positive influence on firm performance. Therefore, the aforementioned findings of Leischnig et al., [3] cannot be generalized. 
Secondly, our findings support the perception of strategy as a set of management decisions regarding how to balance the firm's tradeoffs between being efficient and being effective to achieve objectives [2]. Only the two digital business strategy types processing of intellectual property and orchestration of digital business ecosystems have a positive impact on firm performance. A reason may be that aforementioned two digital business strategy types better balance the tradeoff between being efficient and being effective. Our results thus go in line with findings by Mithas and Rust [20], stating that dual-emphasis firms have stronger profitability relationships than either revenueor cost-emphasis firms.

With regard to business practice. First of all, companies should take a close look at what types of digital business strategy they are currently pursuing and analyze it in respect of its strengths and weaknesses. In our case, the digital business strategy type development of IT applications has a negative impact on the performance of a company but can be a central component of a company's business. If this is the case, companies need to check whether certain mechanisms of other digital business strategy types can be adopted to compensate for the weaknesses of the digital business strategy type they use. For instance, the digital business strategy type development of IT applications processes activities mainly in-house and uses internal resources. However, there are solutions such as open content or value co-creation initiatives to involve external actors in the value creation process and thus reduce costs in the development of software by, simultaneously, increasing generativity through the use of external innovation capacity.

Second, and in line with the aforementioned, in digitally fused environments it is key to practitioners to balance the tradeoff between being efficient and being effective in order to stay competitive. This is made possible above all through the establishment of a digital business ecosystem, as demonstrated by the digital business strategy types processing of intellectual property and orchestration of digital business ecosystems. At the same time, it is difficult to establish these digital business ecosystems due to already existing network and lock-in effects. Therefore, practitioners should carefully consider whether the own market power allows to establish a digital platform business or act as a complementor within an externally hosted digital business ecosystem as both options contain significant risks [19, 38, 76].

\subsection{Limitation and Future Research}

Our study has some limitations worth noting. Overall we restrict our sample by only including the "NASDAQ 100" index and furthermore merely companies from specific SIC industry groups included in this index. This procedure was necessary to obtain a homogeneous sample and to guarantee the availability of the Form $10-\mathrm{K}$ as standardized information source. At the same time, however, the generalizability and transferability of our results must be critically questioned. Firstly, we only examined publicly traded companies. Secondly, we only investigated companies listed on the American stock market. Thirdly, we only examined companies from industries characterized by a high digital maturity. In order to gain more generalizable insights, which would also be valid for smaller firms or other industries, further research should repeat the study with a broader focus (e.g. focusing also on small companies or using

16th International Conference on Wirtschaftsinformatik, March 2021, Essen, Germany 
the MSCI World Information Technology) or include other, more traditional industries, such as the automotive or manufacturing industry. Furthermore, we only record and code fully digital and prototypical business model patterns since we wanted to explore the influence of purely digital strategies on the performance of a company. However, digitally enriched patterns, too, can indicate a digital business strategy. In consequence, we suggest further research to include or focus on digitally enriched business model patterns to gain more insights into digitally enriched strategies. Besides, the identification and characterization of changes of a digital business model is not free from subjectivity, a circumstance our study shares with other studies applying similar approaches [e.g. 62, 78]. In addition, we used the framework derived by Amit and Zott [31] for developing our hypotheses. In doing so, we are in line with several well-known studies using this framework to distinguish between different digital value creation mechanisms. However, it should be noted that the authors, in their initial work, referred to e-business (i.e. business conducted over the Internet). We therefore, are not fully able to guarantee that we cover all value creation mechanisms especially apart from the ebusiness, which may affects the generalizability of our results. Ultimately, we were not able to investigate contingent events that could have affected the performance of companies within our sample. We would therefore encourage further research to examine digital business strategy types and their performance implications via qualitative interviews or case studies.

\section{$9 \quad$ References}

1. Bharadwaj, A., El Sawy, O.A., Pavlou, P.A., Venkatraman, N.: Digital Business Strategy: Toward a Next Generation of Insights. MIS Q. 37, 471-482 (2013).

2. Drnevich, P.L., Croson, D.C.: Information Technology and Business -Level Strategy: Toward an Integrated Theoretical Perspective. MIS Q. 37, 483-509 (2013).

3. Leischnig, A., Wölfl, S., Ivens, B., Hein, D.: From digital business strategy to market performance: Insights into key concepts and processes. In: Thirty Eighth International Conference of Information Systems. , Seoul (2017).

4. Galbraith, C., Schendel, D.: An Empirical Analysis of Strategy Types. Strateg. Manag. J. 4, 153-173 (1983).

5. Porter, M.E.: Competitive Strategy: Technicals for Analyzing Industries and Competitors. Free Press, New York (1980).

6. Ansoff, H.I., Stewart, J.M.: Strategies for a technology-based business. Harv. Bus. Rev. 45, 71-83 (1967).

7. Miles, R., Snow, C.: Organizational Strategy, Structure, and Process. Acad. Manag. Rev. 3, 546-562 (1978).

8. Woodard, C.J., Ramasubbu, N., Tschang, F.T., Sambamurthy, V.: Design Capital and Design Moves: The Logic of Digital Business Strategy. MIS Q. 37, 537-564 (2013).

9. Remane, G., Hanelt, A., Tesch, J.F., Kolbe, L.M.: The Business Model Pattern Database a Tool for Systematic Business Model Innovation. Int. J. Innov. Manag. 21, 1-61 (2017).

10. Casadesus-Masanell, R., Ricart, J.E.: From Strategy to Business Models and onto Tactics. Long Range Plann. 43, 195-215 (2010).

11. Mithas, S., Tafti, A., Mitchell, W.: How a Firm's Competitive Environment and Digital Strategic Posture Influence Digital Business Strategy. MIS Q. 37, 511-536 (2013).

12. Hambrick, D.C.: Some tests of the effectiveness and functional attributes of Miles and Snow’s strategic types. Acad. Manag. J. 26, 5-26 (1983). 
13. Croteau, A.-M., Bergeron, F.: An information technology trilogy: business strategy, technological deployment and organizational performance. J. Strateg. Inf. Syst. 10, 77-99 (2001).

14. Segars, A.H., Grover, V., Kettinger, W.J.: Strategic users of information technology: a longitudinal analysis of organizational strategy and performanc. J. Strateg. Inf. Syst. 3, 261288 (1994).

15. Chan, Y.E., Huff, S.L., Barclay, D.W., Copeland, D.G.: Business Strategic Orientation, Information Systems Strategic Orientation, and Strategic Alignment. Inf. Syst. Res. 8, 125150 (1997).

16. Sabherwal, R., Chan, Y.E.: Alignment Between Business and IS Strategies: A Study of Prospectors, Analyzers, and Defenders. Inf. Syst. Res. 12, 11-33 (2011).

17. Barrett, M., Davidson, E., Prabhu, J., Vargo, S.L.: Service Innovation in the Digital Age: Key Contributions and Future Directions. MIS Q. 39, 135-154 (2015).

18. Tiwana, A., Konsynski, B., Bush, A.A.: Platform Evolution: Coevolution of Platform Architecture, Governance, and Environmental Dynamics. Inf. Syst. Res. 21, 675-687 (2010).

19. Yoo, Y., Henfridsson, O., Lyytinen, K.: The New Organizing Logic of Digital Innovation: An Agenda for Information Systems Research. Inf. Syst. Res. 21, 724-735 (2010).

20. Mithas, S., Rust, R.T.: How Information Technology Strategy and Investments Influence Firm Performance: Conjencture and Empirical Evidence. MIS Q. 40, 223-245 (2016).

21. Chesbrough, H.: Business model innovation: It's not just about technology anymore. Strateg. Leadersh. 35, 12-17 (2007).

22. Demil, B., Lecocq, X.: Business Model Evolution: In Search of Dynamic Consistency. Long Range Plann. 43, 227-246 (2010).

23. Osterwalder, A., Pigneur, Y.: Business Model Generation: A Handbook for Visionaries, Game Changers, and Challengers. Wiley, Hoboken, USA (2010).

24. Teece, D.J.: Business Models, Business Strategy and Innovation. Long Range Plann. 43, 172-194 (2010).

25. Al-Debei, M.M., Avison, D.: Developing a unified framework of the business model concept. Eur. J. Inf. Syst. 19, 359-376 (2010).

26. Lüttgens, D., Diener, K.: Business Model Patterns Used as a Tool for Creating (new) Innovative Business Models. J. Bus. Model. 4, 19-36 (2016).

27. Rudtsch, V., Gausemeier, J., Gesing, J., Mittag, T., Peter, S.: Pattern-based Business Model Development for Cyber-Physical Production Systems. Procedia CIRP. 25, 313-319 (2014).

28. Abdelkafi, N., Makhotin, S., Posselt, T.: Business model innovations for electric mobility: What can be learned from existing business model patterns? Int. J. Innov. Manag. 17, 1-41 (2013).

29. Henfridsson, O., Nandhakumar, J., Scarbrough, H., Panourgias, N.: Recombination in the open-ended value landscape of digital innovation. Inf. Organ. 28, 89-100 (2018).

30. Lyytinen, K., Rose, G.M.: A Knowledge-Based Model of Radical Innovation in Small Software Firms. MIS Q. 36, 865-895 (2012).

31. Amit, R., Zott, C.: Value Creation in E-Business. Strateg. Manag. J. 22, 493-520 (2001)

32. Teece, D.J.: Reflections on "Profiting from Innovation.” Res. Policy. 35, 1131-1146 (2006).

33. Teece, D.J.: Profiting from technological innovation - Implications for integration, collaboration, licensing and public policy. Res. Policy. 15, 285-305 (1986).

34. Shivendu, S., Zhang, R.A.: The Impact of Digitization on Content Markets: Prices, Profit, and Social Welfare. MIS Q. Forthcomin, (2019).

35. Günther, W.A., Rezazade Mehrizi, M.H., Huysman, M., Feldberg, F.: Debating big data: A literature review on realizing value from big data. J. Strateg. Inf. Syst. 26, 191-209 (2017).

36. Loebbecke, C., Picot, A.: Reflections on societal and business model transformation arising from digitization and big data analytics: A research agenda. J. Strateg. Inf. Syst. 24, 149157 (2015). 
37. Gawer, A.: Bridging differing perspectives on technological platforms: Toward an integrative framework. 74th Annu. Meet. Acad. Manag. AOM 2014. 43, 423-428 (2014).

38. Helfat, C.E., Raubitschek, R.S.: Dynamic and integrative capabilities for profiting from innovation in digital platform-based ecosystems. Res. Policy. 47, 1391-1399 (2018).

39. Adner, R., Kapoor, R.: Value Creation in Innovation Ecosystems: How the Structure of Technological Interdependence Affects Firm Performance in new Technology Generations. Strateg. Manag. J. 894, 306-333 (2010).

40. Pagani, M.: Digital Business Strategy and Value Creation: Framing the Dynamic Cycle of Control Points. MIS Q. Manag. Inf. Syst. 37, 617-632 (2013).

41. Zott, C., Amit, R.: The Fit Between Product Market Strategy and Business Model: Implications for Firm Performance. Strateg. Manag. J. 29, 1-26 (2008).

42. Garg, R., Telang, R.: Inferring App Demand from Publicly Available Data. 37, 1253-1264 (2013).

43. Tilson, D., Lyytinen, K., Sørensen, C.: Digital Infrastructures: The Missing IS Research Agenda. Inf. Syst. Res. 21, 748-759 (2010).

44. Kapoor, R., Agarwal, S.: Sustaining Superior Performance in Business Ecosystems: Evidence from Application Software Developers in the iOS and Android Smartphone Ecosystems. Organ. Sci. 28, 531-551 (2017).

45. Kaltenecker, N., Hess, T., Huesig, S.: Managing potentially disruptive innovations in software companies: Transforming from On-premises to the On-demand. J. Strateg. Inf. Syst. 24, 234-250 (2015).

46. Oh, H., Animesh, A., Pinsonneault, A.: Free Versus For-a-Fee: The Impact of a Paywall on the Pattern and Effectiveness of Word-of-Mouth via Social Media. MIS Q. Manag. Inf. Syst. 40, 31-56 (2016).

47. Shapiro, C., Varian, H.R.: Information Rules. Harvard Business School Press, Boston, USA (1998).

48. Oestreicher-Singer, G., Zalmanson, L.: Content or Community? A Digital Business Strategy for Content Providers in the Social Age. MIS Q. 37, 591-616 (2013).

49. Qi Dong, J., Wu, W.: Business value of social media technologies: Evidence from online user innovation communities. J. Strateg. Inf. Syst. 24, 113-127 (2015).

50. Gutt, D., Neumann, J., Zimmermann, S., Kundisch, D., Chen, J.: Design of review systems - A strategic instrument to shape online reviewing behavior and economic outcomes. J. Strateg. Inf. Syst. 28, 104-117 (2019).

51. Animesh, A., Viswanathan, S., Agarwal, R.: Competing "Creatively" in Sponsored Search Markets: The Effect of Rank, Differentiation Strategy, and Competition on Performance. Inf. Syst. Res. 22, 153-169 (2011).

52. Mantena, R., Saha, R.: Co-opetition Between Differentiated Platforms in Two-Sided Markets. J. Manag. Inf. Syst. 29, 109-140 (2012).

53. Bakos, Y., Katsamakas, E.: Design and Ownership of Two-Sided Networks: Implications for Internet Platforms. J. Manag. Inf. Syst. 25, 171-202 (2008).

54. Xu, L., Chen, J., Whinston, A.: Effects of the presence of organic listing in search advertising. Inf. Syst. Res. 23, 1284-1302 (2012).

55. Han, S.P., Park, S., Oh, W.: Mobile App Analytics: A Multiple Discrete-Continuous Choice Framework. MIS Q. 40, 983-1008 (2015).

56. Ceccagnoli, M., Forman, C., Huang, P., WU, D.J.: Cocreation of Value in a Platform Ecosystem - The Case of Enterprise Software. MIS Q. 36, 263-290 (2012).

57. Ondrus, J., Gannamaneni, A., Lyytinen, K.: The impact of openness on the market potential of multi-sided platforms: a case study of mobile payment platforms. J. Inf. Technol. 30, 260-275 (2015).

58. Boudreau, K.: Platform-Based Organization and Boundary Choices: “Opening-Up” While Still Coordinating and Orchestrating. In: Entrepreneurship, Innovation, and Platforms. pp. 227-297. Emerald Publishing Limited (2017). 
59. Mantena, R., Sankaranarayanan, R., Viswanathan, S.: Platform-based information goods: The economics of exclusivity. Decis. Support Syst. 50, 79-92 (2010).

60. Ye, H., Kankanhalli, A.: User Service Innovation on Mobile Phone Platforms: Investigating Impacts of Lead uUerness, Toolkit Support, and Design Autonomy. MIS Q. Manag. Inf. rSyst. 42, 165-187 (2018).

61. Li, C., Peters, G.F., Richardson, V.J.: The Consequences of Information Technology Control Weaknesses on Management Information Systems: The Case of Sarbanes-Oxley Internal Control Reports. MIS Q. 36, 179-203 (2012).

62. Weill, P., Malone, T.W., D’Urso, V., Herman, G., Woerner, S.: Do some business models perform better than others? A study of the 1000 largest US firms. MIT Cent. Coord. Sci. Work. Pap. No. 226. 1-40 (2004).

63. Mayring, P.: Qualitative content analysis: theoretical foundation, basic procedures and software solution. (2014).

64. Montgomery, C.A., Wernerfelt, B.: Diversification, Ricardian Rents, and Tobin’s q Source. RAND J. Econ. 19, 623-632 (1988).

65. Bharadwaj, A.S., Bharadwaj, S.G., Konsynski, B.R.: Information technology effects on firm performance as measured by Tobin’s q. Manage. Sci. 45, 1008-1024 (1999).

66. Kohli, R., Devaraj, S., Ow, T.T.: Does information technology investment influence a firm's market value? A case of non-publicly traded healthcare firms. MIS Q. Manag. Inf. Syst. 36, 1145-1164 (2012).

67. Mithas, S., Tafti, A., Bardhan, I., Goh, J.M.: Information Technology and Firm Profitability. MIS Q. 36, 205-224 (2012).

68. Atasoy, H., Banker, R.D., Pavlou, P.A.: On the Longitudinal Effects of IT Use on FirmLevel Employment. Inf. Syst. Res. 27, 6.26 (2016).

69. Pan, Y., Huang, P., Gopal, A.: Board Independence and Firm Performance in the IT Industry: The Moderating Role of New Entry Threats. MIS Q. 42, 979-1000 (2018).

70. Wooldridge, J.M.: Econometric analysis of cross section and panel data. MIT Press, Cambridge, MA (2002).

71. Pisano, G.P., Teece, D.J.: How to Capture Value from Innovation: Shaping Intellectual Property and Industry Architecture. Calif. Manage. Rev. 50, 278-296 (2007).

72. Teece, D.J.: Profiting from innovation in the digital economy: Enabling technologies, standards, and licensing models in the wireless world. Res. Policy. 47, 1367-1387 (2018).

73. Mansfield, E., Schwartz, M., Wagner, S.: Imitation Costs and Patents: An Empirical Study. Econ. J. 91, 907-918 (1981).

74. Mansfield, E.: How rapidly does new industrial technology leak out? J. Ind. Econ. 217-223 (1985).

75. Holgersson, M., Granstrand, O., Bogers, M.: The evolution of intellectual property strategy in innovation ecosystems: Uncovering complementary and substitute appropriability regimes. Long Range Plann. 51, 303-319 (2018).

76. Yoo, Y., Boland, R.J., Lyytinen, K., Majchrzak, A.: Organizing for Innovation in the Digitized World. Organ. Sci. 23, 1398-1408 (2012).

77. Zhu, F., Liu, Q.: Competing with Complementors: An Empirical Look at Amazon.com. Strateg. Manag. J. 39, 2618-2642 (2018).

78. Dewan, S., Ren, F.: Risk and Return of Information Technology Initiatives: Evidence from Electronic Commerce Announcements. Inf. Syst. Res. 18, 370-394 (2007).

79. Ivari, J.: Information system artefact or information system application: that is the question. Inf. Syst. J. 27, 753-774 (2017). 